\title{
The interaction of laminin and its membrane receptor on mouse macrophage membrane studied by STM and FRAP $^{1}$
}

\author{
WEI XINHUA ${ }^{2}$, YONG ZHAO, XIAOMING DONG, \\ Yaxian SU ${ }^{3}$, Zili MA*, Changxin ZHU*, ShiJin \\ PANG* \\ Dept. of Cell Biology, Beijing Medical University, Beijing \\ 100084, China. \\ *Beijing Vacuum Physics Laboratory, Academia Sinica, \\ Beijing 100083, China.
}

\section{ABSTRACT}

The variation of membrane surface and lateral diffusion of membrane protein was studied after the interaction of laminin with its membrane receptor in mouse macrophages. A pattern of membrane surface which showed smaller and bigger peaks was obtained by scanning tunneling microscope(STM), looking like the domains of lipid groups and proteins in the model of fluid mosaic biomembrane. Some even more higher and wider peaks projected out from the membrane surface in STM image after the interacting of laminin with membrane receptor were, probably, the complexes of laminin and membrane receptor. Furthermore, the decreased lateral diffusion coefficient value $(\bar{D})$ was obtained by fluorescence recovery after photobleaching (FRAP) after the laminin was reacted with membrane receptor. This phenomenon provides an evidence that the complexes of laminin and its membrane receptor were located on the membrane of macrophages. So we could consider that the laminin is combined with membrane receptor leading to the variation in the properties of membrane surface.

Key words: laminin, receptor, macrophage, STM, FRAP.

1.This work supported by a grant from the National Natural Science Foundation.

2.Present address: Research Center of Material Science, Science \& Technology Section,

Beijing Institute of Technology, Beijing 100081, China

3.Corresponding author 


\section{INTRODUCTION}

When a ligand interacted with its receptor on the membrane, a series of changes and responses on cell membrane and inside the cell can be followed. What interests us is the change of the surface membrane pattern during such interaction. Laminin, a glycoprotein molecule constituting of a cross with a long arm and three shorter arms was used as a ligand[1,2] to react specifically with its receptor, an another kind of glycoprotein molecule embe dded in the membrane of mouse macrophage[3]. STM and FR AP were used to study the variation of structure state[4,5] and the lateral diffusion of protein on membrane surface of macrophage, hoping to obtain some useful information about the interaction of laminin and its membrane receptor.

\section{MATERIALS AND METHODS}

Laminin was purified from the Englebreth Holm Swarm (EHS) murine tumor of C57 Black mouse obtained from the Dept. of Cell Biology, Beijing Medical University. Peritoneal macrophages were isolated from Qun Ming line of Swiss mouse by procedures as described by Herscowitz et al[6]. FITC from Sigma Co. U.S.A. The carbon and gold were supplied by Electron Microscope Laboratory, Beijing Medical University. STM measurements were done in Beijing Laboratory of Vacuum Physics, and FRAP measurements in the Institute of Biophysics, both of Academia Sinica, China. Flow Cytometer (FCM) is a FACS 400 from Becton Dickinson Co. U.S. A.

\section{STM measurement}

$1.5 \mathrm{ml}$ peritoneal macrophages were put into the incubation dishes at $37^{\circ} \mathrm{C}$ for 30 rain. The macrophages adhered onto the bottom of the dishes[6] were suspended in $1 \mathrm{ml} 0.9 \%$ saline, and aliquots of $1 \times 10^{8}$ cells/ $\mathrm{ml}$ were used as control and experimental groups. Laminin at a final concentration of $50 \mu \mathrm{g} / \mathrm{ml}$ was put into experimental groups and both incubated for $1 \mathrm{~h}$, then the free laminin was removed by 1,000 rpm centrifugation and washed with saline.

STM measurement was made according to procedures previousty described[4,5]. To prepare base-plate, cover-glasses of $0.2 \mathrm{~mm}$ thickness were first covered with a $100 \mathrm{~nm}$ thin layer of carbon and then a $25 \mathrm{~nm}$ gold layer was spray-gilded on the carbon. The control and treated samples were deposited on two different base-plates, and dried in air shortly. $10 \mu \mathrm{llaminin}$ solution $(1 \mathrm{mg} / \mathrm{ml})$ was dropped on the third base-plate for immediate measurement. The above three base-plates needs to be fixed with electron conducted gel. The tungsten tips were made by electrochemical etching. All images of STM were taken under the same condition: $\mathrm{U}_{t i p}=200 \mathrm{mV}, \mathrm{I}_{t i p}=1 \mathrm{nA}$, room temperature $22^{\circ} \mathrm{C}$.

\section{FRAP measurement}

$1 \mathrm{ml}$ sample of $2 \times 10^{7}$ macrophages was used as experimental group, with laminin added to a final concentration of $100 \mu \mathrm{g} / \mathrm{ml}$; another sample of $1 \mathrm{ml}$ macrophages was used as control. The cells were both incubated and laminin was removed as above.

The membrane proteins and the complexes of laminin and membrane receptor of the cells were labeled with $0.2 \mathrm{ml} \mathrm{FITC}(10 \mu \mathrm{g} / \mathrm{ml})$, incubated at $22^{\circ} \mathrm{C}$ for $30 \mathrm{~min}$. The free FITC was removed by centrifugation and cells were throughtly washed with saline. The suspension of experimental and control cells were deposited on carrier-glass individually, put a drop of 1:1 glycerine: saline on cells, then covered the samples with cover glass. There were no spontaneous fluorescence in both carrier-glass and cover glass.

The value of lateral diffusion coefficient $(\bar{D})$ and of percentage of recovery $(\bar{R})$ of protein complexes of laminin and its receptor on the membrane surface of macrophages were measured by FRAP 
as described previously[7]. The radius of laser beam used was $2.2 \mu \mathrm{m}$ and time of photobleaching was $25 \mathrm{~ms}$ at temperature $22^{\circ} \mathrm{C}$.

\section{FCM measurement}

The laminin $(1 \mathrm{mg} / \mathrm{ml})$ was labeled with FITC $(20 \mu \mathrm{g} / \mathrm{ml})$ by dialysis against the $0.01 M$ PBS buffer $\mathrm{pH} 7.4$ to obtain FITC-laminin.

To $5 \times 10^{6}$ macrophage cells $/ \mathrm{ml}, 80 \mu$ FITC-laminin in $0.9 \%$ saline and then laminin at a final concentration of $80 \mu \mathrm{g} / \mathrm{ml}$ were added and reacted at $37^{\circ} \mathrm{C}$ for $1 \mathrm{~h}$. The free FITC-laminin was removed as above. The treated macrophage sample was measured by FCM and individual fluorescence intensity of 10,000 cells were sorted and determined with FITCex $495 \mathrm{~nm}$, FITCem $516 \mathrm{~nm}$ at temperature $22^{\circ} \mathrm{C}[7]$.

\section{RESULTS AND DISCUSSION}

\section{The pattern of base-plate as a control}

A STM grey-scale image of the surface of base-plate was shown in Fig 1 which displayed a smooth condition of the gold surface.

Fig 1. $\triangleright$ A STM grey-scale image which indicated an even gold surface of base-plate. $\mathrm{X}=\mathrm{Y} 600 \AA$

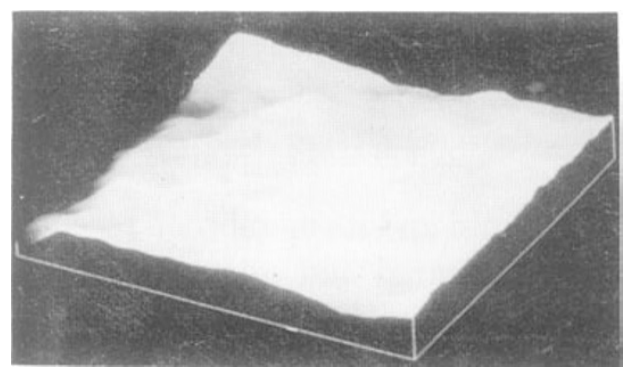

\section{The STM image of a laminin molecule}

Fig 2 was a STM grey-scale image of a laminin molecule in liquid. The shape of laminin molecule was an asymmetry cross which was similar to the image obtained by a special electron microscopy. It has been demonstrated that the membrane receptor of laminin interacted with the cross part of the laminin molecule[1,2]. Sometimes, the surface of four arms of laminin molecule was represented by non-continuous points in grey-scale image because these arms may bend in the liquid.

\section{The membrane surface of macrophage and its change following the interaction of laminin with membrane receptor}

Fig 3 represented a STM grey-scale image of the membrane surface of a control macrophage, displaying a number of bigger and smaller peaks. Although the membrane was in a static state due to the slight drying of the sample, but we considered that the smaller and bigger peaks represented probably the different domain of lipid groups and proteins according to the model of fluid mosaic biomembrane.

A STM grey-scale image of membrane surface pattern of macrophage after its treatment with laminin was shown in Fig 4 There were some even more higher and wider peaks projected out on the plane of membrane which might represent the com- 
Fig 2. $\triangleright$ A STM grey-scale image of a laminin molecule which was suspended in $0.9 \% \mathrm{NaCl}$ solution. A long arm (arrow $\Uparrow)$ and three short arm (arrow head $\triangle$ ) of a laminin molecule could be seen to form a cross. $\mathrm{X}=\mathrm{Y} 110 \stackrel{\mathrm{A}}{\mathrm{N}}$
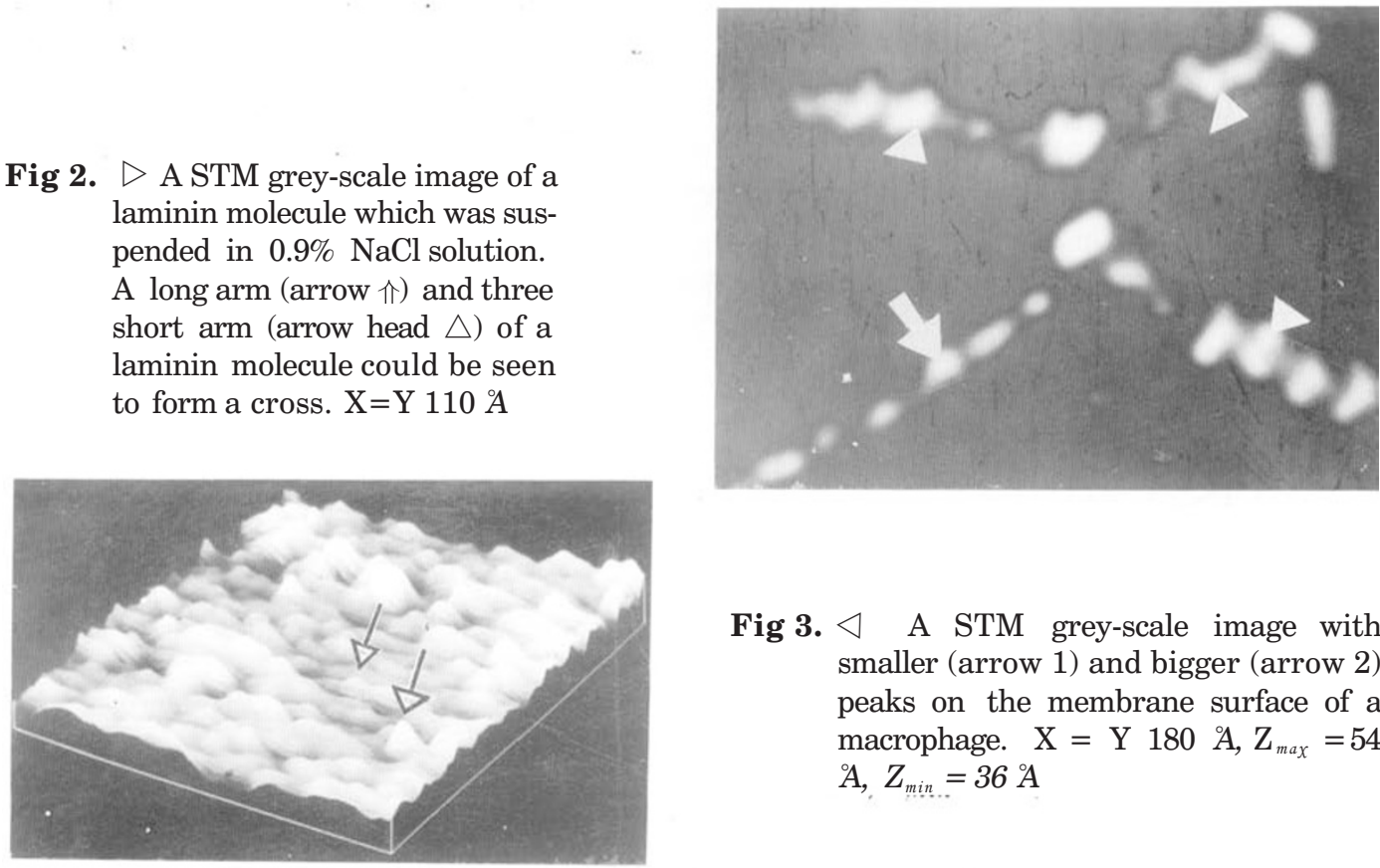

Fig 3. $\triangleleft \quad$ A STM grey-scale image with smaller (arrow 1) and bigger (arrow 2) peaks on the membrane surface of a macrophage. $\mathrm{X}=\mathrm{Y} 180 \AA \mathrm{A}, \mathrm{Z}_{\max }=54$ A, $Z_{\text {min }}=36 \AA$

plexes of laminin and its membrane receptor in aggregated state. In this figure, some long bands appeared and orientated in the same direction. Whether this pattern is related to the non-bilayer arrangement of membrane phospholipid (PE) cannot yet be answered. Similar result was observed in ${ }^{31} \mathrm{p}$ NMR spectrum in the case of ConA-receptor interaction in macrophages[8], but further studies are needed to resolve such a possibility.

Fig 4. $\triangleright$ A STM grey-scale image of the complexes (arrow 3) of laminin and membrane receptor, but its size was much enlarged due possibly to some receptor aggregation after laminin molecules were combined with membrane receptor on a macrophage. $\mathrm{X}=\mathrm{Y} 180 \AA, \mathrm{Z}_{\text {max }}=101 \AA, \mathrm{Z}_{\text {min }}=54 \AA$

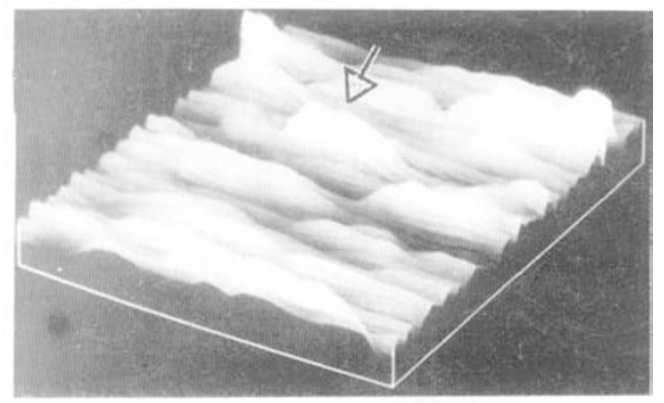

4. The variation of $\bar{D}$ and $\bar{R}$ of macrophage membrane protein after the interaction between laminin and membrane receptor

Tab 1 summarized the value of the lateral diffusion coefficient $(\bar{D})$ and recovery percentage $(\bar{R})$ of the membrane proteins of the control and laminin treated macrophages.

The decrease of $\bar{D}$ value in laminin treated macrophages meant that the speed of 
lateral diffusion of the complexes of laminin and membrane receptor became slower due to the increment of their molecular size. On the contrary, the $\bar{R}$ value of membrane proteins was increased in these cells. Possibly, some complexes had a slow lateral diffusion and acted as non-moving molecules in the area of photobleaching.

We considered that the result of the decrease of the lateral diffusion of membrane protein complexes in laminin-treated macrophages is in fully accordance with the appearance of more big peaks in these cells as shown in STM image Fig 4.

The interaction of the laminin and membrane receptor may be further evidenced from the curve of Fig 5, in which the distribution of laminin combined receptors in the membrane of individual macrophages was represented. We can see that the fluorescence intensity is not equal among individual group of living macrophages due to their difference in the number of laminin receptors.

Tab. 1

\begin{tabular}{cccc}
\hline $\begin{array}{c}\text { Macrophage } \\
\text { sample }\end{array}$ & Cell number & $\bar{D}\left(\times 10^{-9} \mathrm{~cm}^{2} / \mathrm{s}\right.$ & $\bar{R}(\%)$ \\
\hline $\begin{array}{c}\text { control } \\
\text { experimental } \\
(+ \text { laminin })\end{array}$ & 48 & $33.070 \pm 3.973$ & $30.445 \pm 14.531$ \\
\hline $\mathrm{t}$ test & 59 & $8.475 \pm 1.537$ & $46.449 \pm 22.909$ \\
\hline
\end{tabular}

Fig 5. $\triangleright$ A curve obtained by FCM, indicating the distribution of fluorescence intensity among individual macrophages after, their combination with FITC-labeled laminin.

\section{REFERENCES}

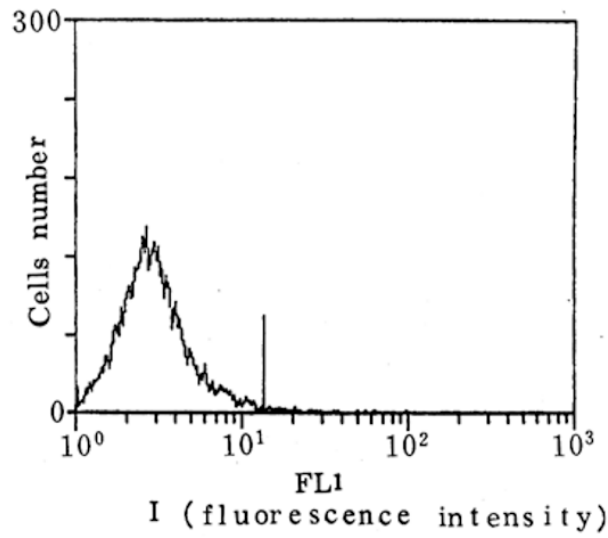

[1] Timpl R, Engel J, Martin GR. Laminin- a multifunctional protein of basement membranes. Trends Biochem Sci 1983; 8:207-9.

[2] Wener U, Albrechtsen R, Mantharpe M, Varon S, Engvall E, Ruoslahti E. Human laminin isolated in a nearly intact biologically active form from placenta by limited proteolysis. J Biol Chem 1983; 258:12654-60.

[3] Mercurio AM, Shaw LM. Macrophage interaction with laminin: PMA selectively induces the adherence and spreading of mouse macrophages on a laminin substratum. J Cell Biol 1988; 107:1873-80. 
[4] Dai JW, Jiao YK, Dong Q, Su YX, Lin KC, He J, et al. The surface structure of natural membrane of macrophages in water as studied by the scanning tunneling microscope. J Vac Sci Technol 1990; B9: 1184-8.

[5] Su YX, Jiao YK, Xu SD, Yao JE, Lin KC. The structure of artificial and natural membranes as studied by STM. J Vac Sci Technol 1990; A8:695-7.

[6] Herscowitz, HB, Holden HT, Bellanti JA, Ghaffar A. In: "Manual of macrophage methodology". New York and Besel 1981; pp5-11.

[7] Su YX, Xiao JJ, Wang S, Cai YH, Huang YN, Qing SP. Assembly of F-actin and motility of ascitic liver cancer cells under the action of extrinsic laminin. Acta Biophysica Sinica 1989; 5:160-6.

[8] Dai JW, Qun D, Su YX, Lin KC. Effect of ConA-receptor interaction on the structure of cell membrane. Cell Research 1992; 2:129-37.

Recieved 8-9-91. Revised 20-5-92. Accepted 20-6-92. 